\title{
THE EFFECT OF INCREASED NITROGEN LEVELS ON SOIL CO EMISSION CAUSED BY MICROBIAL RESPIRATION IN THE RIPARIAN ZONE OF THE THREE GORGES RESERVOIR
}

\author{
HE, L. P. * - LiN, J. J. - LAN, B. - DUAN, L. Y. - XU, Z. J. - LiAO, Y. H. \\ Key Laboratory of Water Environment Evolution and Pollution Control in the Three Gorges \\ Reservoir, Chongqing Three Georges University, Chongqing 404100, China \\ *Corresponding author \\ e-mail: hlp_weird@163.com \\ (Received $9^{\text {th }}$ Sep 2020; accepted $30^{\text {th }}$ Nov 2020)
}

\begin{abstract}
The increase of atmospheric nitrogen deposition has greatly affected soil $\mathrm{CO}_{2}$ emission caused by microbial respiration, probably resulting in the acceleration of global warming. However, the effect of atmospheric nitrogen deposition on soil $\mathrm{CO}_{2}$ emission is not still entirely clear, especially in riparian zone ecosystems. In this study, we studied the riparian zone of the Three Gorges Reservoir after a 36-d soil incubation with four nitrogen species, including $\mathrm{NH}_{4} \mathrm{Cl}, \mathrm{NaNO}_{3}, \mathrm{CO}\left(\mathrm{NH}_{2}\right)_{2}$ and $\mathrm{CO}\left(\mathrm{NH}_{2}\right)_{2}(28 \%)$, as well as $\mathrm{NH}_{4} \mathrm{NO}_{3}(72 \%)$ with three nitrogen addition levels to the soil at $44.39,88.77$ and $133.16 \mu \mathrm{g} \mathrm{N} \mathrm{g}^{-1}$. Soil cumulative carbon respiration was promoted by $13.37 \%, 21.55 \%$ and $27.59 \%$ with the nitrogen addition of $44.39,88.77$ and $133.16 \mu \mathrm{g} \mathrm{N} \mathrm{g}^{-1}$ soil, respectively, increasing linearly with the increase of nitrogen addition levels. However, it was not changed with the nitrogen species. In conclusion, soil cumulative carbon respiration increased with the nitrogen addition levels regardless of the nitrogen species. Thus, induced by atmospheric nitrogen deposition, soil $\mathrm{CO}_{2}$ emission from riparian zone should not be ignored in the twenty-first century.
\end{abstract}

Keywords: atmospheric nitrogen deposition, soil cumulative carbon respiration, the Yangtze River, nitrogen species

\section{Introduction}

Atmospheric nitrogen $(\mathrm{N})$ deposition has increased more than 10-fold since the industrial revolution (Holland et al., 1999) and it will continuously do so in the coming decades (Galloway et al., 2008). The increase of atmospheric $\mathrm{N}$ deposition has greatly affected soil $\mathrm{CO}_{2}$ emission caused by microbial respiration (He et al., 2018; Meyer et al., 2018), probably resulting in the acceleration of global warming. Therefore, assessing the effect of atmospheric $\mathrm{N}$ deposition increase on soil microbial respiration is an urgent issue.

A large number of studies have examined this scientific problem and found that atmospheric $\mathrm{N}$ deposition inhibits (Riggs and Hobbie, 2016; Li et al., 2017; Peng et al., 2020), promotes (Tu et al., 2013; Fang et al., 2017; Liang et al., 2018), or does not change (Peng et al., 2010; He et al., 2018; Zhao et al., 2020) soil microbial respiration in forest, grassland, pasture, cropland and wetland ecosystems. This dispute may be due to the difference of $\mathrm{N}$ addition species, $\mathrm{N}$ addition levels and soil properties. Firstly, inconsistent results were also discovered between the addition of ammonium and nitrate (Puri and Ashman, 1999; Min et al., 2011) and between that of inorganic and organic N (Ramirez et al., 2010; Du et al., 2014). Secondly, high level of ammonium addition relatively inhibits soil microbial respiration compared to that of nitrate (Min et al., 2011; Li et al., 2017) because the decline of soil acidity caused by ammonium addition is larger than that caused by nitrate addition. Finally, changed by $\mathrm{N}$ increase, soil properties such as $\mathrm{pH}$ 
(Rousk et al., 2009; Chen et al., 2016; Li et al., 2017), dissolved organic carbon (DOC) (Wang et al., 2003; Chen et al., 2014; Eberwein et al., 2015) and Carbon (C):N ratio (Gong et al., 2019) are closely related to soil microbial respiration. Therefore, treated with different $\mathrm{N}$ species and levels, more soil ecosystems with different soil properties should be investigated for the accurate assessment of the effect of $\mathrm{N}$ increase on soil $\mathrm{C}$ loss by microbial respiration from the terrestrial ecosystem.

The riparian zone of the Three Gorges Reservoir (TGR) is the largest one in the world (Bao et al., 2015), locating in the third-largest $\mathrm{N}$ deposition area of the world. The atmospheric $\mathrm{N}$ flux in this area is even as high as $50 \mathrm{~kg} \mathrm{~N} \mathrm{ha}^{-1} \mathrm{a}^{-1}$ with the composition of $72 \%$ inorganic $\mathrm{N}$ and $28 \%$ organic $\mathrm{N}$ (Yuan et al., 2009; Zhang et al., 2020). The soil of the riparian zone is exposed to air when it comes out of water, which is conducive to the rapid propagation of aerobic microorganisms. Meanwhile, atmospheric $\mathrm{N}$ deposition will alleviate the $\mathrm{N}$ limitation of soil microbial metabolism, which may lead to a large amount of soil $\mathrm{C}$ respiration loss from the riparian zone (Chen et al., 2014; Kamble and Baath, 2016). Thus, the influence of $\mathrm{N}$ deposition on soil $\mathrm{C}$ loss by microbial respiration should be concerned in the riparian zone of the TGR.

In this study, we aimed to discuss the effect of atmospheric $\mathrm{N}$ deposition on soil $\mathrm{CO}_{2}$ emission caused by microbial respiration based on a 36-d soil incubation executed by four $\mathrm{N}$ species with three $\mathrm{N}$ addition levels. We hypothesized that: ( $\mathrm{i}$ ) soil microbial respiration would be promoted by the increased $\mathrm{N}$ addition levels and the decreased soil $\mathrm{C}: \mathrm{N}$ ratio; ( ii ) the $\mathrm{N}$ species had no significant effect on soil microbial respiration.

\section{Materials and methods}

\section{Site description and soil sampling}

The riparian zone of the TGR is located in the transection area of Chongqing and Hubei province, China. It is a north subtropical humid monsoonal climatic with an average annual temperature of $18.2^{\circ} \mathrm{C}$ and an average annual precipitation of $1053.15 \mathrm{~mm}$ (1981-2018, https//power. larc. nasa. gov). It has experienced continuous artificial drying-rewetting cycles since 2003. The area of its mainstream and tributaries is about $349 \mathrm{~km}^{2}(\mathrm{He}, 2011)$. A year is divided into the dry period and the flooding period, according to the fluctuation of the water level caused by the operation of the TGR and the dry period is about six months (Chen et al., 2019b). During the dry period, the soil of the riparian zone exposes to air, whereas during the flooding period, it is inundated by the water of the TGR.

Intact soil was randomly collected from the riparian zone of the TGR within the Wanzhou section $\left(\mathrm{N} 30^{\circ} 47.28^{\prime} \sim 30^{\circ} 50.10^{\prime}\right.$, E108 $21.35^{\prime} \sim 108^{\circ} 23.41^{\prime}$, Fig. 1$)$ by polypropylene containers $(13.5 \mathrm{~cm} \times 10.02 \mathrm{~cm} \times 6.8 \mathrm{~cm})$ in June 2017 . After the sampling, the containers were sealed tightly, stored at $4^{\circ} \mathrm{C}$ and immediately transported to a laboratory within $24 \mathrm{~h}$. Soil physicochemical properties are listed in Table 1.

\section{Experimental design and soil incubation}

Nitrogen treatments consisted of four $\mathrm{N}$ species $\left(\mathrm{NH}_{4} \mathrm{Cl}, \mathrm{NaNO}_{3}, \mathrm{CO}\left(\mathrm{NH}_{2}\right)_{2}\right.$, $\mathrm{CO}\left(\mathrm{NH}_{2}\right)_{2}(28 \%)$ plus $\mathrm{NH}_{4} \mathrm{NO}_{3}(72 \%)$ ) with three $\mathrm{N}$ levels $(44.39,88.77$ and $133.16 \mu \mathrm{g} \mathrm{N} \mathrm{g}^{-1}$ soil). Meanwhile, a control without $\mathrm{N}$ treatment was set up. Three replicates were set up for both the control and the $\mathrm{N}$ treatments. In total, we incubated 39 jars $((4 \times 3+1) \times 3)$. 


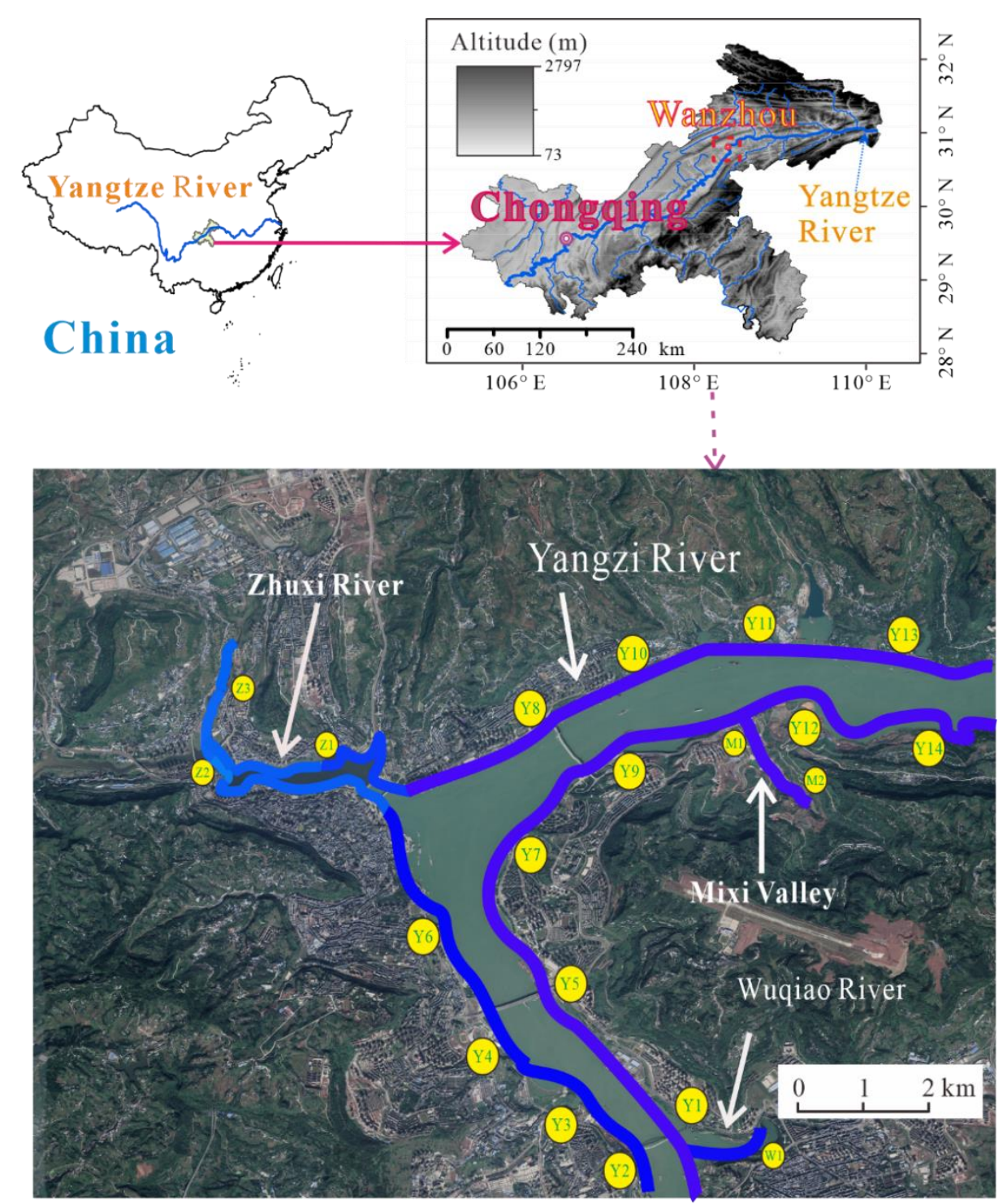

Figure 1. Soil sample sites

Table 1. Soil physicochemical properties in the riparian zone

\begin{tabular}{c|c}
\hline Physicochemical properties & Values \\
\hline $\mathrm{pH}$ & $8.55(0.03)$ \\
total C $\left(\mathrm{mg} \mathrm{g}^{-1}\right)$ & $14.83(0.24)$ \\
total N $\left(\mathrm{mg} \mathrm{g}^{-1}\right)$ & $0.27(0.01)$ \\
$\mathrm{C} / \mathrm{N} \mathrm{ratio}$ & $54.36(1.43)$ \\
DOC $\left(\mathrm{mg} \mathrm{kg}^{-1}\right)$ & $61.38(1.35)$ \\
Gravimetric water content (\%) & $40.00(0.91)$ \\
Clay (\%) & $10.55(5.25)$ \\
Silt (\%) & $23.40(7.87)$ \\
Sand (\%) & $66.05(15.23)$ \\
\hline
\end{tabular}

Note: values represent means of three replicates with standard deviation in parenthesis

First, $200 \mathrm{~g}$ soil was placed in $470 \mathrm{~mL}$ jars as quickly as possible and stabilized at ambient temperature for three days to avoid soil disturbance. After the stabilization, the 
jars were added with $50 \mathrm{~mL} \mathrm{~N}$ solution (corresponding to the above $\mathrm{N}$ treatments) every 10 days and incubated in a growth chamber (SW-96P, Sang woo scientific, Korea) at $20^{\circ} \mathrm{C}$ in the dark for 36 days. After four times of $\mathrm{N}$ solution addition, the $\mathrm{N}$ addition levels were $44.39,88.77$ and $133.16 \mu \mathrm{g} \mathrm{N} \mathrm{g}^{-1}$ soil corresponding to the atmospheric $\mathrm{N}$ deposition fluxes of 50, 100 and $150 \mathrm{~kg} \mathrm{~N} \mathrm{ha}^{-1} \mathrm{a}^{-1}$, respectively. The controls were added with four times of $50 \mathrm{~mL}$ deionized water. All samples were destructed for chemical analysis at the end of the incubation.

\section{Soil respiration rate and cumulative $C$ respiration}

Soil respiration rate $\left(\mathrm{R}_{\mathrm{s}}\right)$ was measured on the day of $1,2,4,6,8,15,22,29$ and 36. Before gas sampling, each jar was sealed airtight to accumulate $\mathrm{CO}_{2}$ for $1 \mathrm{~h}$. The headspace gas was extracted by a $10 \mathrm{~mL}$ syringe equipped with a three-way stopcock (Discofix $\circ, \mathrm{R}$ C, B. Braun, Germany) through a septum in the middle of a lid at the start and the end of the $\mathrm{CO}_{2}$ accumulative period. The collected gas was stored in a $5 \mathrm{ml}$ syringe (GASTIGHT॰,R \#1005 Hamilton, Shimadzu, Japan), and then was injected into a gas chromatography (GC7890, Agilent Technologies, USA) for analysing the $\mathrm{CO}_{2}$ concentration. $\mathrm{R}_{\mathrm{s}}$ was calculated according to the method of Robertson et al. (1999).

Soil cumulative $\mathrm{C}$ respiration $\left(\mathrm{C}_{\mathrm{um}}\right)$ was calculated as Eq.1 (Lin et al., 2015):

$$
C_{u m(i+1)}=\frac{\left(R_{i+1}+R_{i}\right) \times\left(t_{i+1}-t_{i}\right) \times 24}{2}+C_{u m(i)}
$$

where $\mathrm{C}_{\mathrm{um}(\mathrm{i}+1)}$ is $\mathrm{C}_{\mathrm{um}}$ on the $i+1$ sampling time $\left(\mu \mathrm{g} \mathrm{CO} \mathrm{CO}_{2}-\mathrm{C} \mathrm{g}^{-1}\right.$ soil, $\left.i=1, \mathrm{C}_{\mathrm{um}(\mathrm{i})}=0\right)$; $\mathrm{R}_{\mathrm{i}+1}$ is $\mathrm{R}_{\mathrm{s}}$ on the $\mathrm{i}+1$ sampling time ( $\mu \mathrm{g} \mathrm{CO}_{2}-\mathrm{C} \mathrm{g}^{-1}$ soil hr-1), $\mathrm{t}$ is the sample time (d).

\section{Soil physicochemical properties}

Soil $\mathrm{pH}$ was determined in a soil: water (1:2.5 w/w) slurry (Orion $3 \mathrm{Star}$, Thermo Electron, USA). Total $\mathrm{C}$ and $\mathrm{N}$ content were detected by an element analyser (EA5000, Elementar, Germany). DOC was extracted with $10 \mathrm{ml}$ deionized water (soil: water $=1: 10$ $\mathrm{w} / \mathrm{w}$ ), then filtered through a $0.45 \mu \mathrm{m}$ filter (ALBET). Finally, it was determined by a total organic carbon analyser (TOC-LCPH/CPN, Shimadzu, Japan). Soil gravimetric water content was measured by drying $1 \mathrm{~g}$ soil in a furnace at $105^{\circ} \mathrm{C}$ for $24 \mathrm{~h}$, and then was weighted. The distribution of soil particle size was analysed by hydrometer method (Ashworth et al., 2001).

\section{Data analysis}

The differences of $R_{s}$ among the soil treatments were assessed by a repeated measure ANOVA after normality test (Shapiro-Wilk test). An exponential decay function was applied to explore the relationship between $R_{s}$ and the incubation time, and a linear function was used to detect the relationship between $\mathrm{C}_{\mathrm{um}}$ and the varieties of soil chemical properties. A two-way ANOVA was used to determine the statistical differences of $\mathrm{C}_{\mathrm{um}}$ and the soil chemical properties after the incubation among the $\mathrm{N}$ addition species and levels at $P<0.05$. The influence factors of soil respiration in terms of soil chemical properties were analysed by a principal component analysis (PCA) based on the standardization datum of soil $\mathrm{pH}, \mathrm{C}: \mathrm{N}$ ratio, $\mathrm{DOC}$, total $\mathrm{C}$ and total $\mathrm{N}$ after the incubation. All statistical analyses were performed by IBM SPSS 17.0 for windows. 


\section{Results}

\section{Soil $\mathrm{CO}_{2}$ emission}

Soil respiration rate decreased rapidly during the initial $6 \mathrm{~d}$ and then tended to be stable, which was accorded with the trend of exponential decay for all the $\mathrm{N}$ treatments (Fig. 2). $\mathrm{N}$ addition significantly promoted $\mathrm{R}_{\mathrm{s}}$, especially during $1-4$ days $(P<0.05)$. Compared to the control, $\mathrm{C}_{\mathrm{um}}$ was promoted by $13.37 \%$ (i.e. $50 \mathrm{~kg} \mathrm{~N}^{-1} \mathrm{aa}^{-1}$ ), $21.55 \%$ (i.e. $100 \mathrm{~kg} \mathrm{~N} \mathrm{ha}^{-1} \mathrm{a}^{-1}$ ) and $27.59 \%$ (i.e. $150 \mathrm{~kg} \mathrm{~N} \mathrm{ha}^{-1} \mathrm{a}^{-1}$ ) (Fig. 3, $P<0.05$ ), increasing linearly with the $\mathrm{N}$ addition levels for all the $\mathrm{N}$ species (Fig. 4, P<0.05). $\mathrm{C}_{\mathrm{um}}$ was significantly influenced by the increase of $\mathrm{N}$ levels $(P<0.001)$, but not changed with the $\mathrm{N}$ species (Table 2, $P=0.129$ ).

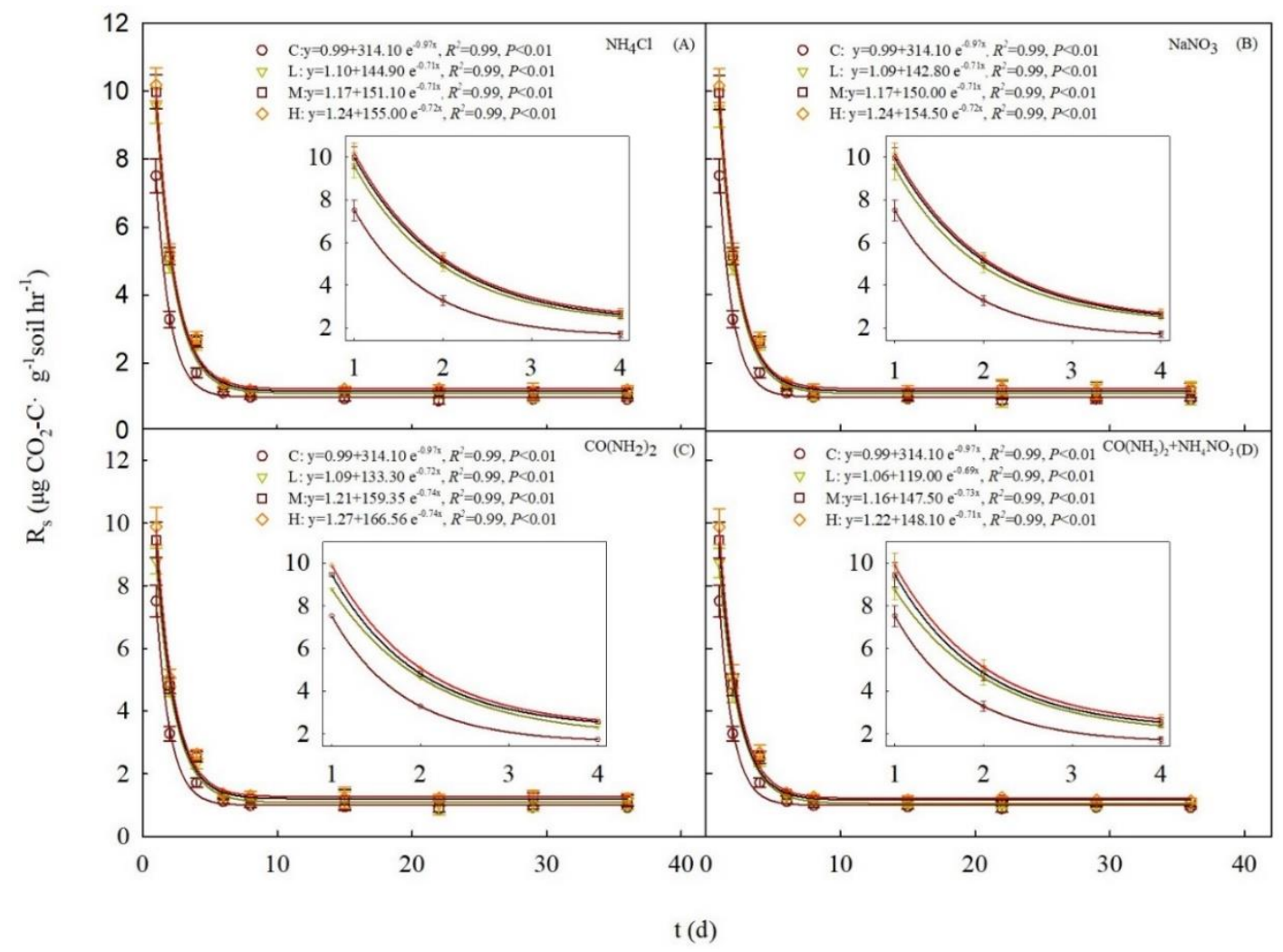

Figure 2. Soil respiration rate $\left(R_{s}\right)$ during the 36-d incubation. $C, L, M$ and $H$ represent the $N$ addition of $0,44.39,88.77$ and $133.16 \mu \mathrm{g} \mathrm{g}^{-1}$ soil, respectively. " $y$ " and " $x$ " represent $R_{s}$ and the incubation time, respectively. Bars represent the standard deviations of the mean $(n=3)$

\section{The varieties of soil chemical properties}

Compared to the control, soil $\mathrm{pH}$ significantly decreased under $\mathrm{NH}_{4} \mathrm{Cl}$ (Table 3, $P<0.05)$, but was not significantly changed under $\mathrm{NaNO}_{3}, \mathrm{CO}\left(\mathrm{NH}_{2}\right)_{2}$ and $\mathrm{CO}\left(\mathrm{NH}_{2}\right)_{2}$ plus $\mathrm{NH}_{4} \mathrm{NO}_{3}(P>0.05)$ at the end of the incubation. Soil DOC increased by $3.85 \%$, while total $\mathrm{C}$ decreased by $0.59 \%$ across the $\mathrm{N}$ treatments, not changed by the $\mathrm{N}$ addition species and levels (Table 2, $P>0.05$ ). Soil $\mathrm{C}: \mathrm{N}$ ratio decreased and total $\mathrm{N}$ increased, with the $\mathrm{N}$ addition levels for all the $\mathrm{N}$ species (Tables 2 and 3, $P<0.001$ ). 


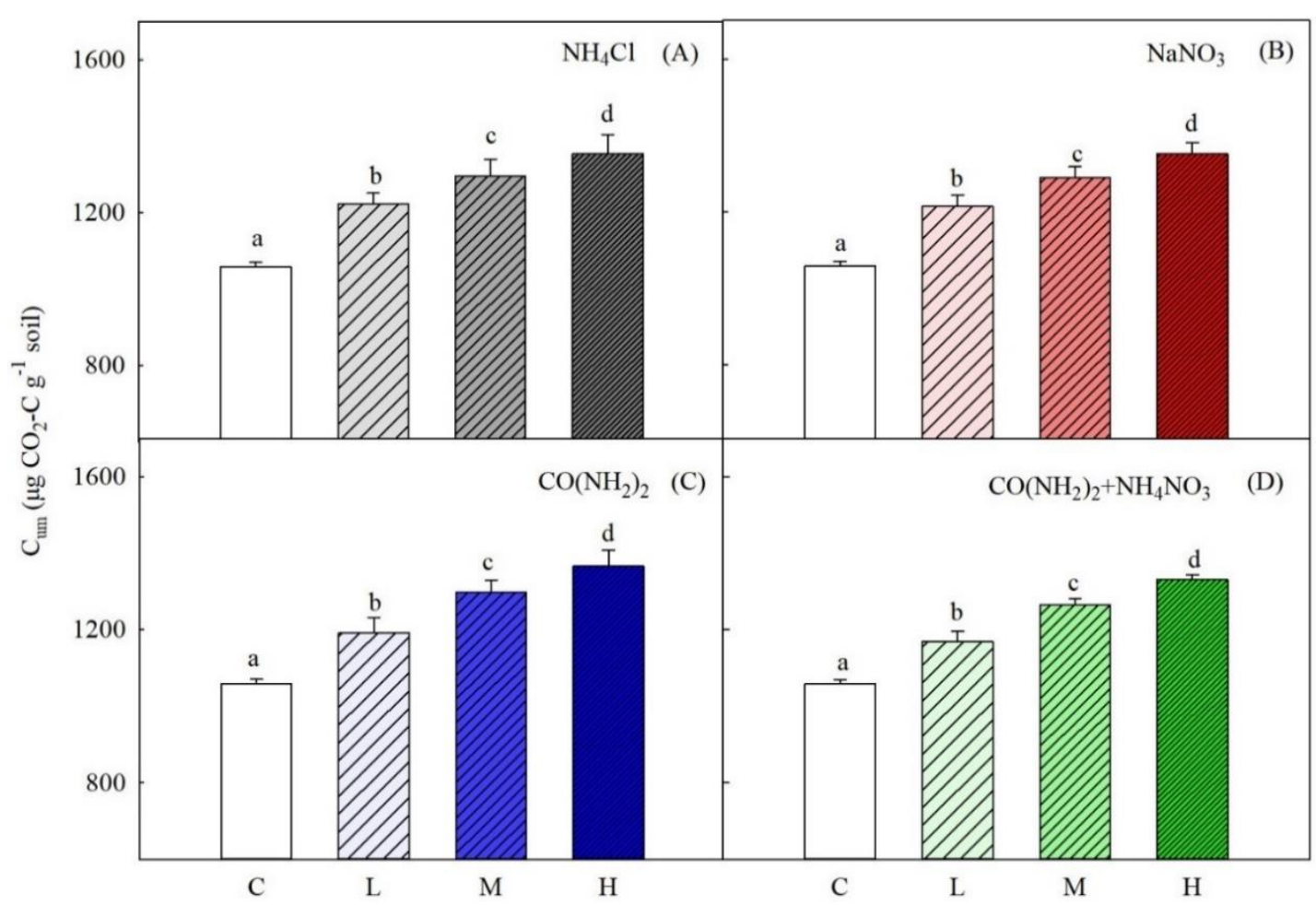

Figure 3. Cumulative soil $C$ respiration $\left(C_{u m}\right)$ under the $N$ treatments after the 36-d incubation. $C, L, M$ and $H$ represent the $N$ addition of $0,44.39,88.77$ and $133.16 \mu g \mathrm{Ng}^{-1}$ soil, respectively. Different lowercases represent the significant differences among the $N$ addition levels $(P<0.05)$; Bars represent the standard deviations of the mean $(n=3)$

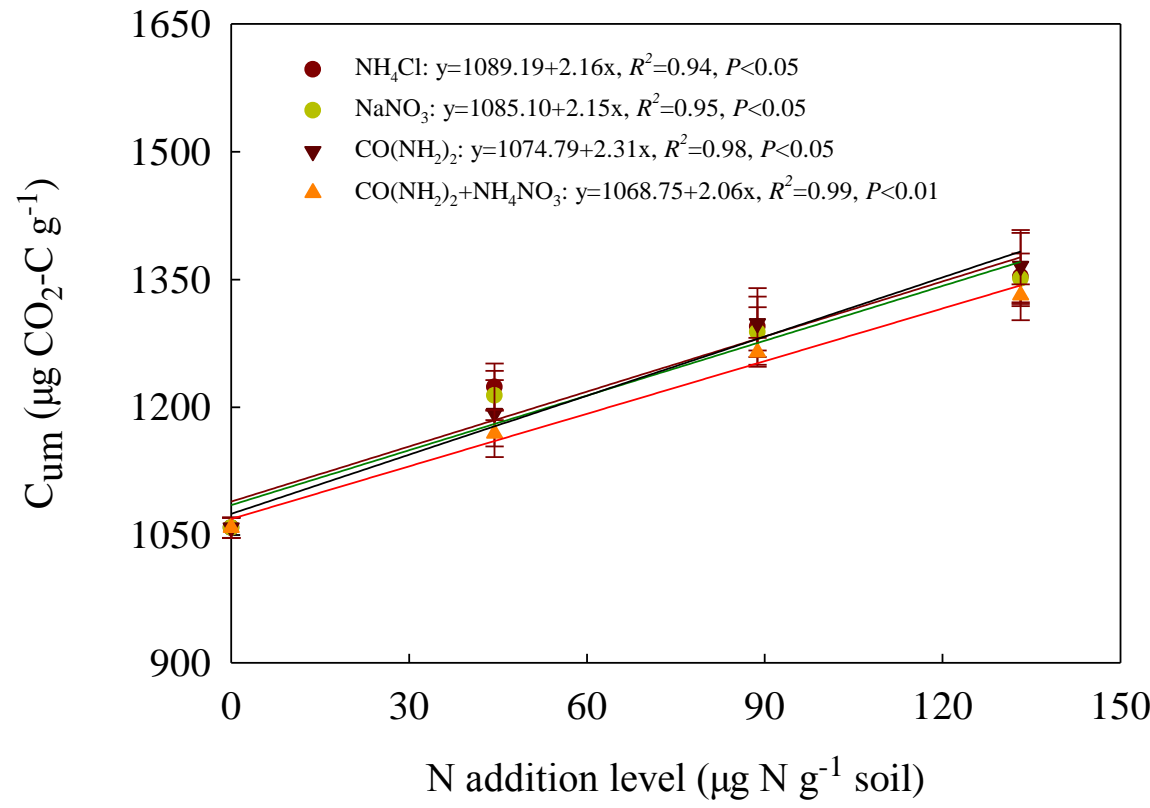

Figure 4. The relationship between Cumulative soil $C$ respiration $\left(C_{u m}\right)$ and the $N$ addition levels. " $y$ " and " $x$ " represent $C_{u m}$ and the $N$ addition level, respectively. Bars represent the standard deviations of the mean $(n=3)$ 
Table 2. Results from two-way ANOVA ( $P$ values) to test the effects of $N$ addition species and levels on Cumulative soil C respiration $\left(C_{u m}\right)$ and soil chemical properties

\begin{tabular}{c|c|c|c}
\hline \multirow{2}{*}{ Response variable } & \multicolumn{2}{|c|}{ Main effects } & Interaction effects \\
\cline { 2 - 4 } & N species & N levels & N species*N levels \\
\hline $\mathrm{pH}$ & 0.001 & 0.523 & 0.245 \\
Total C & 0.300 & 0.990 & 1.000 \\
Total N & $<0.001$ & $<0.001$ & 0.003 \\
$\mathrm{C} / \mathrm{N}$ & 1.000 & $<0.001$ & 1.000 \\
$\mathrm{DOC}$ & 0.883 & 0.545 & 0.145 \\
$\mathrm{Cum}_{\mathrm{um}}$ & 0.129 & $<0.001$ & 0.925 \\
\hline
\end{tabular}

Note: $\mathrm{n}=36$

Table 3. Soil chemical properties at the end of the incubation

\begin{tabular}{|c|c|c|c|c|c|}
\hline \multirow{2}{*}{ N species } & \multirow{2}{*}{$\begin{array}{l}\text { Chemical } \\
\text { properties }\end{array}$} & \multicolumn{4}{|c|}{ 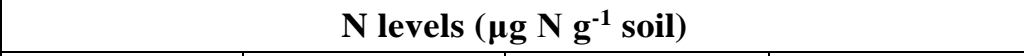 } \\
\hline & & C & $\mathrm{L}$ & M & $\mathrm{H}$ \\
\hline \multirow{5}{*}{$\mathrm{NH}_{4} \mathrm{Cl}$} & $\mathrm{pH}$ & $7.95(0.08) \mathrm{a}$ & $7.75(0.07) b$ & $7.82(0.01) b$ & $7.78(0.04) b$ \\
\hline & Total C $\left(\mathrm{mg} \mathrm{g}^{-1}\right)$ & $13.74(0.29)$ & $13.67(0.19)$ & $13.65(0.24)$ & $13.64(0.22)$ \\
\hline & Total $\mathrm{N}\left(\mathrm{mg} \mathrm{kg}^{-1}\right)$ & $270.33(9.50) \mathrm{a}$ & $299.92(9.10) \mathrm{b}$ & $329.51(9.50) \mathrm{c}$ & $359.10(9.50) \mathrm{d}$ \\
\hline & $\mathrm{C} / \mathrm{N}$ & $50.86(1.07) \mathrm{a}$ & $45.61(0.80) \mathrm{b}$ & $41.44(0.60) \mathrm{c}$ & $37.99(0.46) \mathrm{d}$ \\
\hline & DOC $\left(\mathrm{mg} \mathrm{kg}^{-1}\right)$ & $57.19(1.71)$ & $59.91(1.78)$ & $60.03(1.50)$ & $57.46(0.67)$ \\
\hline \multirow{5}{*}{$\mathrm{NaNO}_{3}$} & $\mathrm{pH}$ & $7.95(0.08)$ & $7.94(0.04)$ & $7.92(0.06)$ & $7.91(0.08)$ \\
\hline & Total C $\left(\mathrm{mg} \mathrm{g}^{-1}\right)$ & $13.74(0.29)$ & $13.68(0.19)$ & $13.65(0.20)$ & $13.64(0.25)$ \\
\hline & Total $\mathrm{N}\left(\mathrm{mg} \mathrm{kg}^{-1}\right)$ & $270.33(9.50) \mathrm{a}$ & $298.34(10.02) b$ & $331.28(10.77) \mathrm{c}$ & $360.76(10.21) d$ \\
\hline & $\mathrm{C} / \mathrm{N}$ & $50.86(1.07) \mathrm{a}$ & $45.60(0.81) \mathrm{b}$ & $41.44(0.58) \mathrm{c}$ & $38.00(0.45) \mathrm{d}$ \\
\hline & $\operatorname{DOC}\left(\mathrm{mg} \mathrm{kg}^{-1}\right)$ & $57.19(1.71)$ & $58.85(2.25)$ & $60.54(1.84)$ & $58.76(0.73)$ \\
\hline \multirow{5}{*}{$\mathrm{CO}\left(\mathrm{NH}_{2}\right)_{2}$} & $\mathrm{pH}$ & $7.95(0.08)$ & $7.91(0.13)$ & $7.88(0.05)$ & $7.86(0.04)$ \\
\hline & Total C $\left(\mathrm{mg} \mathrm{g}^{-1}\right)$ & $13.74(0.29)$ & $13.68(0.28)$ & $13.66(0.19)$ & $13.66(0.28)$ \\
\hline & Total $\mathrm{N}\left(\mathrm{mg} \mathrm{kg}^{-1}\right)$ & $270.33(9.50) \mathrm{a}$ & $300.42(8.90) \mathrm{b}$ & $331.67(9.48) \mathrm{c}$ & $361.44(10.27) d$ \\
\hline & $\mathrm{C} / \mathrm{N}$ & $50.86(1.07) \mathrm{a}$ & $45.63(0.76) \mathrm{b}$ & $41.46(0.62) \mathrm{c}$ & $38.04(0.49) \mathrm{d}$ \\
\hline & $\operatorname{DOC}\left(\mathrm{mg} \mathrm{kg}^{-1}\right)$ & $57.19(1.71)$ & $60.13(1.68)$ & $60.52(2.15)$ & $58.56(0.73)$ \\
\hline \multirow{5}{*}{$\begin{array}{c}\mathrm{CO}\left(\mathrm{NH}_{2}\right)_{2} \\
\text { plus } \\
\mathrm{NH}_{4} \mathrm{NO}_{3}\end{array}$} & $\mathrm{pH}$ & $7.95(0.08)$ & $7.90(0.12)$ & $7.89(0.07)$ & $7.84(0.08)$ \\
\hline & Total C $\left(\mathrm{mg} \mathrm{g}^{-1}\right)$ & $13.74(0.29)$ & $13.68(0.20)$ & $13.66(0.21)$ & $13.65(0.20)$ \\
\hline & Total $\mathrm{N}\left(\mathrm{mg} \mathrm{kg}^{-1}\right)$ & $270.33(9.50) \mathrm{a}$ & 299.67 (9.17) b & $328.77(8.99) \mathrm{c}$ & $361.29(9.13) \mathrm{d}$ \\
\hline & $\mathrm{C} / \mathrm{N}$ & $50.86(1.07) \mathrm{a}$ & $45.62(0.77) b$ & $41.45(0.57) \mathrm{c}$ & $38.41(0.45) \mathrm{d}$ \\
\hline & $\mathrm{DOC}\left(\mathrm{mg} \mathrm{kg}^{-1}\right)$ & $57.19(1.71)$ & $60.39(1.94)$ & $58.23(0.73)$ & $59.27(2.28)$ \\
\hline
\end{tabular}

Note: values represent means of three replicates with standard deviation in parenthesis. Means within each row followed by different lowercases represent a significant difference among the $\mathrm{N}$ levels $(\mathrm{P}<0.05)$

\section{The relationship between $C_{u m}$ and the varieties of soil chemical properties}

Soil cumulative $\mathrm{C}$ respiration was negatively and linearly related to the varieties of soil C: $\mathrm{N}$ ratio and total $\mathrm{C}$ (Fig. $5 A$ and $E, P<0.01$ ), while positively and linearly related to the varieties of soil total $\mathrm{N}$ ( Fig. $5 B, P<0.01$ ). No significant correlations were observed between $\mathrm{C}_{\mathrm{um}}$ and the varieties of soil $\mathrm{pH}$ and DOC (Fig. 5C-D, P>0.05). 

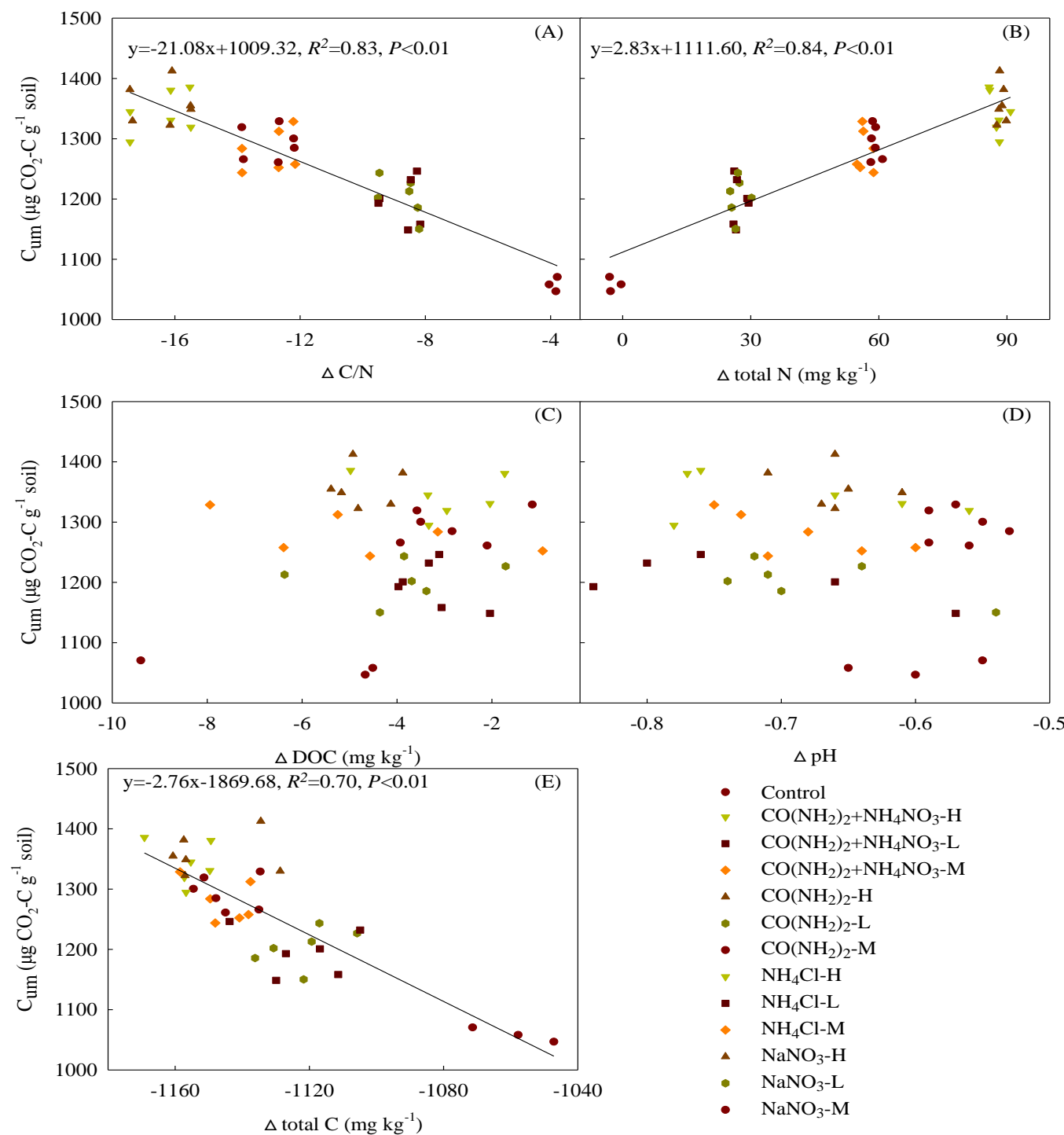

- Control

$\checkmark \mathrm{CO}\left(\mathrm{NH}_{2}\right)_{2}+\mathrm{NH}_{4} \mathrm{NO}_{3}-\mathrm{H}$

- $\mathrm{CO}\left(\mathrm{NH}_{2}\right)_{2}+\mathrm{NH}_{4} \mathrm{NO}_{3}-\mathrm{L}$

- $\mathrm{CO}\left(\mathrm{NH}_{2}\right)_{2}+\mathrm{NH}_{4} \mathrm{NO}_{3}-\mathrm{M}$

$\triangle \mathrm{CO}\left(\mathrm{NH}_{2}\right)_{2}-\mathrm{H}$

- $\mathrm{CO}\left(\mathrm{NH}_{2}\right)_{2}-\mathrm{L}$

- $\mathrm{CO}\left(\mathrm{NH}_{2}\right)_{2}-\mathrm{M}$

v $\mathrm{NH}_{4} \mathrm{Cl}-\mathrm{H}$

- $\mathrm{NH}_{4} \mathrm{Cl}-\mathrm{L}$

- $\mathrm{NH}_{4} \mathrm{Cl}-\mathrm{M}$

- $\mathrm{NaNO}_{3}-\mathrm{H}$

- $\mathrm{NaNO}_{3}-\mathrm{L}$

- $\mathrm{NaNO}_{3}-\mathrm{M}$

Figure 5. The relationships between Cumulative soil C respiration $\left(C_{u m}\right)$ and the varieties of the chemical properties. $L, M$ and $H$ represent the $N$ addition of $44.39,88.77$ and $133.16 \mu \mathrm{g} \mathrm{Ng}^{-1}$ soil, respectively. " $\Delta$ " represents the varieties of the soil chemical properties before and after the incubation. " $y$ " and " $x$ " represent the variables in horizontal and vertical coordinates

\section{Discussion}

Our results indicated that $\mathrm{C}_{\mathrm{um}}$ increased with the $\mathrm{N}$ addition levels by alleviating soil microbial $\mathrm{N}$ limitation regardless of the $\mathrm{N}$ species (Fig. 6), which would result in a large amount of soil $\mathrm{CO}_{2}$ emission from riparian zone in the future. Thus, induced by atmospheric $\mathrm{N}$ deposition, soil $\mathrm{CO}_{2}$ emission should be concerned in riparian zone.

\section{The effect of $\mathrm{N}$ addition levels on soil $\mathrm{C} / \mathrm{N}$ ratio and $\mathrm{CO}_{2}$ emission}

Soil C: $\mathrm{N}$ ratio decreased with the $\mathrm{N}$ addition levels for all the $\mathrm{N}$ species (Table 2 and Table 3, $P<0.001)$. Soil total $\mathrm{N}$ increased with the $\mathrm{N}$ addition levels $(P<0.001)$, which is the reason for the results. Gong et al. (2019) discovered the same trend in a field study of temperate grassland. 


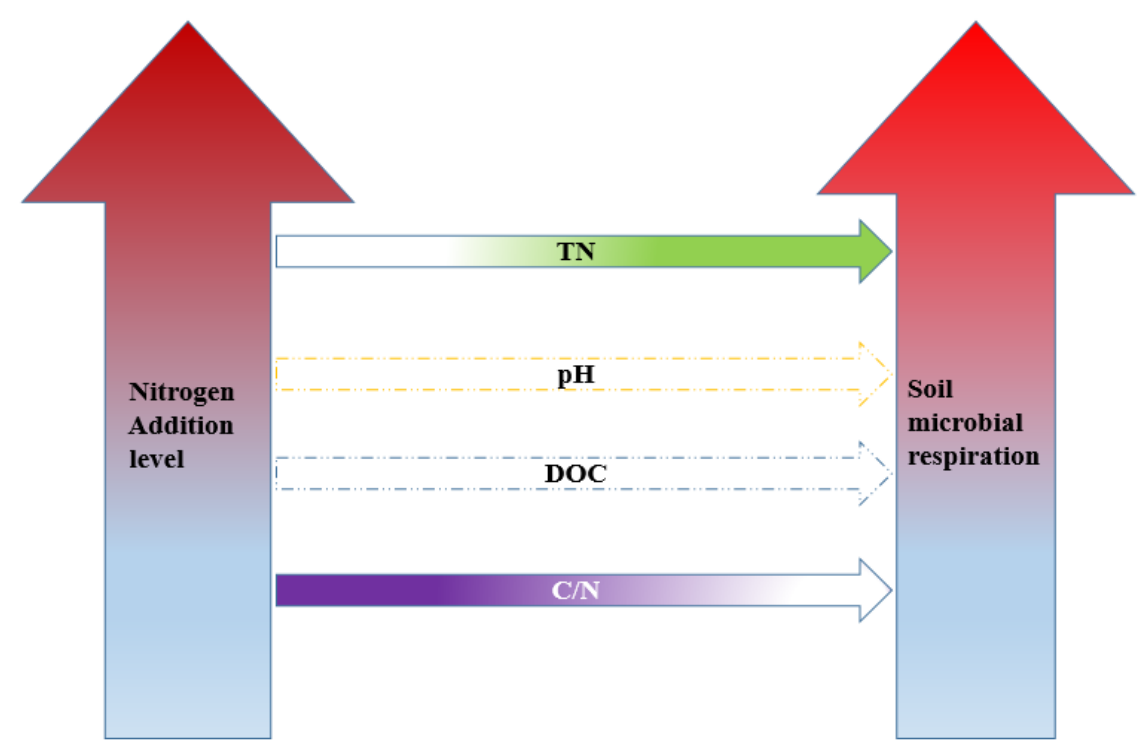

Figure 6. The response of soil microbial respiration to the $N$ addition levels in terms of the varieties of soil chemical properties. The colours of the arrows changing from light to dark and from dark to light represent the increase and decrease of soil chemical properties, respectively.

Dash and solid lines represent insignificant and significant relationships, respectively

As we hypothesized, $\mathrm{C}_{\mathrm{um}}$ increased with the $\mathrm{N}$ addition levels for all the $\mathrm{N}$ species (Fig. 3, $P<0.05$ ). The alleviation of soil microbial nutrition limitation is the reason for the results, supported by the results of PCA (PC1 represented by soil C: $\mathrm{N}$ ratio and total $\mathrm{N}$, Fig. 7) and the negatively linear relationship between $\mathrm{C}_{\mathrm{um}}$ and the variety of soil $\mathrm{C}: \mathrm{N}$ ratio (Fig. 5A, $P<0.01$ ). $\mathrm{N}$ addition increases soil microbial respiration in forest, pasture, grassland, wetland, cropland and bamboo ecosystems, which is consistent with our results; Meanwhile, inconsistent results of inhibiting and no effect were also observed (Table 4). The differences of soil $\mathrm{pH}$ and $\mathrm{C}$ and $\mathrm{N}$ availability (Leifeld et al., 2008; Eberwein et al., 2015) might be the reasons for the inconformity.

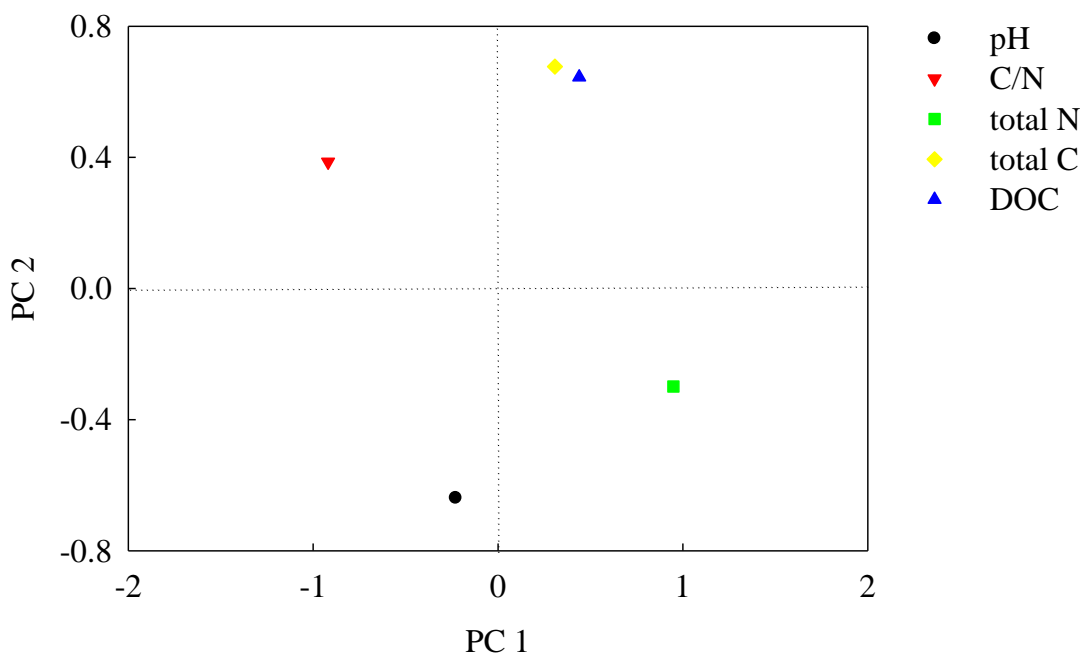

Figure 7. The principal component analysis (PCA) of the soil chemical properties after the incubation. The first two principal components (PCs) account for 41 and $30 \%$ of the variances in the soil chemical properties 
Table 4. The response of soil respiration to $N$ addition in different soil ecosystems

\begin{tabular}{|c|c|c|c|c|}
\hline Ecosystems & N species & $\begin{array}{c}\text { N levels } \\
\left(\mathrm{kg} \mathrm{N} \mathrm{ha}^{-1} \mathbf{y r}^{-1}\right)\end{array}$ & $\begin{array}{l}\text { Response of soil } \\
\text { respiration } \\
\text { to N addition }\end{array}$ & References \\
\hline \multirow{7}{*}{ Forest } & $\mathrm{NH}_{4} \mathrm{NO}_{3}$ & 100 & - & (Zheng et al., 2018) \\
\hline & $\mathrm{NH}_{4} \mathrm{NO}_{3}$ & 100 & - & (Li et al., 2017) \\
\hline & $\mathrm{NH}_{4} \mathrm{NO}_{3}$ & 50,150 & - & (Peng et al., 2020) \\
\hline & $\mathrm{NH}_{4} \mathrm{NO}_{3}$ & 50 & + & (Sun et al., 2019) \\
\hline & $\mathrm{NH}_{4} \mathrm{NO}_{3}$ & 50 & + & (Chen et al., 2019a) \\
\hline & $\mathrm{CO}\left(\mathrm{NH}_{2}\right)_{2}$ & 50,100 & ns & (Zhao et al., 2018) \\
\hline & $\mathrm{NH}_{4} \mathrm{NO}_{3}$ & $50,150,300$ & - & (Yan et al., 2020) \\
\hline \multirow{3}{*}{ Pasture } & $\mathrm{NH}_{4} \mathrm{NO}_{3}$ & 44.20 & + & (Fang et al., 2017) \\
\hline & $\mathrm{CO}\left(\mathrm{NH}_{2}\right)_{2}$ & 100 & + & (Wang et al., 2020) \\
\hline & $\mathrm{NH}_{4} \mathrm{NO}_{3}$ & $<8,>8$ & $\mathrm{~ns},-$ & (Wang et al., 2019b) \\
\hline \multirow{8}{*}{ Grassland } & $\mathrm{CO}\left(\mathrm{NH}_{2}\right)_{2}$ & 100 & - & $\begin{array}{c}\text { (Riggs and Hobbie, } \\
\text { 2016) }\end{array}$ \\
\hline & $\mathrm{CO}\left(\mathrm{NH}_{2}\right)_{2}$ & $100,200,300,400,500$ & - & (Zeng et al., 2018) \\
\hline & $\mathrm{CO}\left(\mathrm{NH}_{2}\right)_{2}$ & 100 & - & (Riggs et al., 2015) \\
\hline & $\mathrm{CO}\left(\mathrm{NH}_{2}\right)_{2}$ & 23,92 & + & (Zhang et al., 2014) \\
\hline & $\mathrm{CO}\left(\mathrm{NH}_{2}\right)_{2}$ & 100 & $\mathrm{~ns}$ & (Zhao et al., 2020) \\
\hline & $\mathrm{NH}_{4} \mathrm{NO}_{3}$ & 50,100 & $\mathrm{~ns}$ & (He et al., 2018) \\
\hline & $\mathrm{NH}_{4} \mathrm{NO}_{3}$ & 44.2 & $\mathrm{~ns}$ & (Fang et al., 2018) \\
\hline & $\mathrm{CO}\left(\mathrm{NH}_{2}\right)_{2}$ & 100,200 & - & (Wei et al., 2018) \\
\hline \multirow{3}{*}{ Wetland } & $\mathrm{NH}_{4} \mathrm{NO}_{3}$ & $\begin{array}{c}0.10,0.20,0.50 \mathrm{mg} \mathrm{N} \\
\mathrm{g}^{-1} \text { soil }\end{array}$ & - & (Tao et al., 2013) \\
\hline & $\mathrm{NH}_{4} \mathrm{NO}_{3}$ & 30,60 & - & (Min et al., 2011) \\
\hline & $\mathrm{NH}_{4} \mathrm{NO}_{3}$ & 40,80 & + & (Wang et al., 2019a) \\
\hline Bamboo & $\mathrm{NH}_{4} \mathrm{NO}_{3}$ & 50,100 & + & (Tu et al., 2013) \\
\hline Cropland & $\mathrm{CO}\left(\mathrm{NH}_{2}\right)_{2}$ & $120,180,240$ & + & (Liang et al., 2018) \\
\hline $\begin{array}{l}\text { Riparian } \\
\text { zone }\end{array}$ & \begin{tabular}{|c|}
$\mathrm{NH}_{4} \mathrm{Cl}, \mathrm{NaNO}_{3}$ \\
$\mathrm{CO}\left(\mathrm{NH}_{2}\right)_{2}$ \\
$\mathrm{CO}\left(\mathrm{NH}_{2}\right)_{2}(28 \%)$ plus \\
$\mathrm{NH}_{4} \mathrm{NO}_{3}(72 \%)$ \\
\end{tabular} & $50,100,150$ & + & This study \\
\hline
\end{tabular}

Note: "+", “-" and "ns" represent promoting, inhibiting and no significant impact of $\mathrm{N}$ addition on soil microbial respiration

\section{The effect of $\mathrm{N}$ species on soil $\mathrm{CO}_{2}$ emission}

Again, as we hypothesized, the $\mathrm{N}$ species had no effect on $\mathrm{C}_{\mathrm{um}}$ (Fig. 3 and Table 2, $P>0.05$ ), which is supported by the results of Ramirez et al. (2010). However, Du et al. (2014) discovered that inorganic and organic $\mathrm{N}$ addition inhibits and promotes soil microbial respiration, respectively, and Wang et al. (2018) found that the mixture addition of inorganic and organic $\mathrm{N}$ has higher inhibition on soil microbial respiration than single organic or inorganic $\mathrm{N}$ addition, which are inconsistent with our results. This inconformity should be due to the difference of soil microbial activity caused by different $\mathrm{N}$ addition species and soil properties (Geisseler and Scow, 2014), and needs a further study. 
The results suggested that soil $\mathrm{CO}_{2}$ emission from riparian zone caused by atmospheric $\mathrm{N}$ deposition should be considered when we establish an estimation model of soil $\mathrm{CO}_{2}$ emission from the terrestrial ecosystem. In addition, for improving the ecological effect of the TGR, land management measures should be taking to reduce exogenous $\mathrm{N}$ input to the riparian zone during the dry period.

\section{Conclusion}

This study discussed the effect of nitrogen increase on soil carbon dioxide emission caused by microbial respiration in the riparian zone of the Three Gorges Reservoir based on a 36-d soil incubation. The increase of the nitrogen addition levels decreased soil carbon: nitrogen ratio and promoted soil microbial respiration regardless of the nitrogen species. The findings suggest that, induced by atmospheric nitrogen deposition, soil carbon dioxide emission should be concerned in riparian zone. However, a long-term soil incubation should be launched for the better understanding of the effect of exogenous nitrogen input on soil microbial carbon dioxide emission. Meanwhile, this study only discussed the effect of nitrogen increase on soil microbial respiration in terms of soil chemical properties; the deep microbial mechanism should be discussed in the future.

Acknowledgments. This work was supported by the National Natural Science Foundation of China (31770529); Program of Chongqing Science and Technology Commission (cstc2018jcyjAX0813); the Science and Technology Research Program of Chongqing Municipal Education Commission (KJ1710260, KJQN201801233, KJZD-K201801201); the Chongqing Municipal Key Laboratory of Institutions of Higher Education (WEPKL2016LL-03).

\section{REFERENCES}

[1] Ashworth, J., Keyes, D., Kirk, R., Lessard, R. (2001): Standard procedure in the hydrometer method for particle size analysis. - Communications in Soil Science and Plant Analysis 32(56): 633-642.

[2] Bao, Y., Gao, P., He, X. (2015): The water-level fluctuation zone of Three Gorges Reservoir - a unique geomorphological unit. - Earth-science Reviews 150: 14-24.

[3] Chen, R., Senbayram, M., Blagodatsky, S., Myachina, O., Dittert, K., Lin, X., Blagodatskaya, E., Kuzyakov, Y. (2014): Soil C and N availability determine the priming effect: microbial $\mathrm{N}$ mining and stoichiometric decomposition theories. - Global Change Biology 20(7): 2356-2367.

[4] Chen, D., Li, J., Lan, Z., Hu, S., Bai, Y., Niu, S. (2016): Soil acidification exerts a greater control on soil respiration than soil nitrogen availability in grasslands subjected to longterm nitrogen enrichment. - Functional Ecology 30(4): 658-669.

[5] Chen, F., Yan, G., Xing, Y., Zhang, J., Wang, Q., Wang, H., Huang, B., Hong, Z., Dai, G., Zheng, X. (2019a): Effects of N addition and precipitation reduction on soil respiration and its components in a temperate forest. - Agricultural and Forest Meteorology 271: 336-345.

[6] Chen, X., Zhang, S., Liu, D., Yu, Z., Zhou, S., Li, R., Liu, Z., Lin, J. (2019b): Nutrient inputs from the leaf decay of Cynodon dactylon (L.) Pers in the water level fluctuation zone of a Three Gorges tributary. - Science of The Total Environment 688: 718-723.

[7] Du, Y., Guo, P., Liu, J., Wang, C., Yang, N., Jiao, Z. (2014): Different types of nitrogen deposition show variable effects on the soil carbon cycle process of temperate forests. Global Change Biology 20(10): 3222-3228. 
[8] Eberwein, J. R., Oikawa, P. Y., Allsman, L. A., Jenerette, G. D. (2015): Carbon availability regulates soil respiration response to nitrogen and temperature. - Soil Biology and Biochemistry 88: 158-164.

[9] Fang, C., Ye, J. S., Gong, Y., Pei, J., Yuan, Z., Xie, C., Zhu, Y., Yu, Y. (2017): Seasonal responses of soil respiration to warming and nitrogen addition in a semi-arid alfalfa-pasture of the Loess Plateau, China. - Science of The Total Environment 590-591: 729-738.

[10] Fang, C., Li, F., Pei, J., Ren, J., Gong, Y., Yuan, Z., Ke, W., Zheng, Y., Bai, X., Ye, J. (2018): Impacts of warming and nitrogen addition on soil autotrophic and heterotrophic respiration in a semi-arid environment. - Agricultural and Forest Meteorology 248: 449457.

[11] Galloway, J. N., Townsend, A. R., Erisman, J. W., Bekunda, M., Cai, Z., Freney, J. R., Martinelli, L. A., Seitzinger, S. P., Sutton, M. A. (2008): Transformation of the nitrogen cycle: recent trends, questions, and potential solutions. - Science 320(5878): 889-892.

[12] Geisseler, D., Scow, K. M. (2014): Long-term effects of mineral fertilizers on soil microorganisms - A review. - Soil Biology and Biochemistry 75: 54-63.

[13] Gong, S., Zhang, T., Guo, J. (2019): Warming and nitrogen addition change the soil and soil microbial biomass C:N:P stoichiometry of a meadow steppe. - International Journal of Environmental Research and Public Health 16(15): 2705.

[14] He, X. B. (2011): Preliminary study on soil erosion at the water-level-fluctuating zone of the Three Gorges Reservoir. - Research of Soil and Water Conservation 18(06): 190-195.

[15] He, Y., Qi, Y., Dong, Y., Peng, Q., Guo, S., Yan, Z., Li, Z., Wang, L. (2018): Effects of changing $\mathrm{C}$ and $\mathrm{N}$ availability on soil respiration dynamics in a temperate grassland in northern China. - Geoderma 329: 20-26.

[16] Holland, E. A., Dentener, F. J., Braswell, B. H., Sulzman, J. M. (1999): Contemporary and pre-industrial global reactive nitrogen budgets. - Biogeochemistry 46(3): 7-43.

[17] Kamble, P. N., Baath, E. (2016): Comparison of fungal and bacterial growth after alleviating induced N-limitation in soil. - Soil Biology and Biochemistry 103: 97-105.

[18] Leifeld, J., Zimmermann, M., Fuhrer, J. (2008): Simulating decomposition of labile soil organic carbon: effects of pH. - Soil Biology and Biochemistry 40(12): 2948-2951.

[19] Li, Y., Sun, J., Tian, D., Wang, J., Ha, D., Qu, Y., Jing, G., Niu, S. (2017): Soil acid cations induced reduction in soil respiration under nitrogen enrichment and soil acidification. Science of The Total Environment 615: 1535-1546.

[20] Liang, G., Cai, A., Wu, H., Wu, X., Cai, D. (2018): Soil biochemical parameters in the rhizosphere contribute more to changes in soil respiration and its components than those in the bulk soil under nitrogen application in croplands. - Plant and Soil 449(8): 681-687.

[21] Lin, J., Zhu, B., Cheng, W. (2015): Decadally cycling soil carbon is more sensitive to warming than faster-cycling soil carbon. - Global Change Biology 21(12): 4602-4612.

[22] Meyer, N., Welp, G., Rodionov, A., Borchard, N., Martius, C., Amelung, W. (2018): Nitrogen and phosphorus supply controls soil organic carbon mineralization in tropical topsoil and subsoil. - Soil Biology and Biochemistry 119: 152-161.

[23] Min, K., Kang, H., Lee, D. (2011): Effects of ammonium and nitrate additions on carbon mineralization in wetland soils. - Soil Biology and Biochemistry 43(12): 2461-2469.

[24] Peng, Q., Dong, Y., Qi, Y., Xiao, S., He, Y., Ma, T. (2010): Effects of nitrogen fertilization on soil respiration in temperate grassland in Inner Mongolia, China. - Environmental Earth Sciences 62(6): 1163-1171.

[25] Peng, Y., Song, S., Li, Z., Li, S., Chen, G., Hu, H., Xie, J., Chen, G., Xiao, Y., Liu, L. (2020): Influences of nitrogen addition and aboveground litter-input manipulations on soil respiration and biochemical properties in a subtropical forest. - Soil Biology and Biochemistry 142: 107694.

[26] Puri, G., Ashman, M. R. (1999): Microbial immobilization of ${ }^{15} \mathrm{~N}$-labelled ammonium and nitrate in a temperate woodland soil. - Soil Biology and Biochemistry 31(6): 929-931. 
[27] Ramirez, K. S., Craine, J. M., Fierer, N. (2010): Nitrogen fertilization inhibits soil microbial respiration regardless of the form of nitrogen applied. - Soil Biology and Biochemistry 42(12): 2336-2338.

[28] Riggs, C. E., Hobbie, S. E. (2016): Mechanisms driving the soil organic matter decomposition response to nitrogen enrichment in grassland soils. - Soil Biology and Biochemistry 99: 54-65.

[29] Robertson, G. P., Coleman, D. C., Bledsoe, C. S., Sollins, P. (1999): Standard soil methods for long-term ecological research. - Oxford University Press, New York.

[30] Rousk, J., Brookes, P. C., Baath, E. (2009): Contrasting soil pH effects on fungal and bacterial growth suggest functional redundancy in carbon mineralization. - Applied and Environmental Microbiology 75(6): 1589-1596.

[31] Sun, S., Wu, Y., Zhang, J., Wang, G., Deluca, T. H., Zhu, W., Li, A., Duan, M., He, L. (2019): Soil warming and nitrogen deposition alter soil respiration, microbial community structure and organic carbon composition in a coniferous forest on eastern Tibetan Plateau. - Geoderma 353: 283-292.

[32] Tao, B., Song, C., Guo, Y. (2013): Short-term effects of nitrogen additions and increased temperature on wetland soil respiration, Sanjiang Plain, China. - Wetlands 33(4): 727-736.

[33] Tu, L. H., Hu, T. X., Zhang, J., Li, X. W., Hu, H. L., Liu, L., Xiao, Y. L. (2013): Nitrogen addition stimulates different components of soil respiration in a subtropical bamboo ecosystem. - Soil Biology and Biochemistry 58: 255-264.

[34] Wang, W., Dalal, R. C., Moody, P. W., Smith, C. J. (2003): Relationships of soil respiration to microbial biomass, substrate availability and clay content. - Soil Biology and Biochemistry 35(2): 273-284.

[35] Wang, Q., Liu, S., Wang, Y., Tian, P., Sun, T. (2018): Influences of N deposition on soil microbial respiration and its temperature sensitivity depend on $\mathrm{N}$ type in a temperate forest. - Agricultural and Forest Meteorology 260-261: 240-246.

[36] Wang, J., Fu, X., Zhang, Z., Li, M., Cao, H., Zhou, X., Ni, H., Wang, X. (2019a): Responses of soil respiration to nitrogen addition in the Sanjiang Plain wetland, northeastern China. Plos One 14(1): e0211456.

[37] Wang, J., Song, B., Ma, F., Tian, D., Li, Y., Yan, T., Quan, Q., Zhang, F., Li, Z., Wang, B. (2019b): Nitrogen addition reduces soil respiration but increases the relative contribution of heterotrophic component in an alpine meadow. - Functional Ecology 33(11): 22392253.

[38] Wang, Y., Wang, D., Shi, B., Sun, W. (2020): Differential effects of grazing, water, and nitrogen addition on soil respiration and its components in a meadow steppe. - Plant and Soil 447(1): 581-598.

[39] Wei, L., Su, J., Jing, G., Zhao, J., Liu, J., Cheng, J., Jin, J. (2018): Nitrogen addition decreased soil respiration and its components in a long-term fenced grassland on the Loess Plateau. - Journal of Arid Environments 152: 37-44.

[40] Xu, W., Zhao, Y., Liu, X., Dore, A. J., Zhang, L., Liu, L., Cheng, M. (2018): Atmospheric nitrogen deposition in the Yangtze River basin: spatial pattern and source attribution. Environmental Pollution 232: 546-555.

[41] Yan, W., Chen, X., Peng, Y., Zhu, F., Zhen, W., Zhang, X. (2020): Response of soil respiration to nitrogen addition in two subtropical forest types. - Pedosphere 30: 478-486.

[42] Yuan, L., Zhou, X. B., Gu, X. Y. (2009): Temporal and spatial variation of atmospheric wet nitrogen deposition in typical areas of Chongqing. - Acta Ecologica Sinica 29(11): 6095-6101.

[43] Zeng, W., Chen, J., Liu, H., Wang, W. (2018): Soil respiration and its autotrophic and heterotrophic components in response to nitrogen addition among different degraded temperate grasslands. - Soil Biology and Biochemistry 124: 255-265.

[44] Zhang, C., Niu, D., Hall, S. J., Wen, H., Li, X., Fu, H., Wan, C., Elser, J. J. (2014): Effects of simulated nitrogen deposition on soil respiration components and their temperature sensitivities in a semiarid grassland. - Soil Biology and Biochemistry 75: 113-123. 
[45] Zhang, L., Tian, M., Peng, C., Fu, C., Yang, F. (2020): Nitrogen wet deposition in the Three Gorges Reservoir area: Characteristics, fluxes, and contributions to the aquatic environment. - Science of The Total Environment 738: 140309.

[46] Zhao, B., Wang, J. S., Cao, J., Xiu, H., Gadow, K. V. (2018): Inconsistent autotrophic respiration but consistent heterotrophic respiration responses to 5-years nitrogen addition under natural and planted pinus tabulaeformis forests in northern China. - Plant and Soil 429(1): 375-389.

[47] Zhao, X., Li, Y., Xie, Z., Li, P. (2020): Effects of nitrogen deposition and plant litter alteration on soil respiration in a semiarid grassland. - Science of The Total Environment 740: 139634.

[48] Zheng, S., Bian, H., Quan, Q., Xu, L., Chen, Z., He, N. (2018): Effect of nitrogen and acid deposition on soil respiration in a temperate forest in China. - Geoderma 329: 82-90. 